\title{
The influence of geological structure on glacial erosion and lake basins formation
}

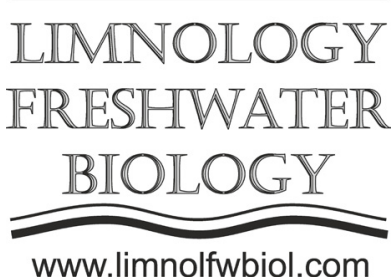

\author{
Amantov A.V. ${ }^{1 *}$, Amantova M.G. ${ }^{1}$, Sapelko T.V. ${ }^{2}$ \\ ${ }^{1}$ A.P. Karpinsky Russian Geological Research Institute (VSEGEI), St. Petersburg, Russia \\ ${ }^{2}$ Institute of Limnology, RAS, St. Petersburg, Russia
}

\begin{abstract}
The geomorphological evolution of several huge lake basins in the Pleistocene glacial and periglacial domains was analyzed with the combination of relevant modeling and geological data. It is found that most basins were occupied by large lakes classified as structural - denudational forms, when the pattern of uneven glacial erosion was influenced by geological and tectonic features. The basins were divided into groups on the basis of their peculiarities and resulting morphological changes.
\end{abstract}

Keywords: Quaternary, large lakes, glaciation, geology, tectonics, erosion, modeling

\section{Introduction}

It is widely accepted that most lakes were formed as a result of the Pleistocene glacial activity, and it shaped many basins linked to existing freshwater large lakes. They often represent small permanent remnants of the huge dammed temporary glacial lakes created in front of the paleo-ice sheets of Northern Hemisphere. There are ongoing discussions about "glacial" vs. "tectonic" or "astrobleme" (e.g. Lake Beloye (60.17 N, $37.65 \mathrm{E}$ ), one of the ten biggest natural lakes in Europe) origin of several basins. We here revisit the shaping of huge possibly glacial lake basins in relation to the tectonic and geological framework, using simulation models of sediment redistribution in key areas.

\section{Materials and methods}

Estimation of erosion and deposition was performed by automated regional geologicalgeomorphological analysis and rate-based time-scale reconstructions using the Geolednik - Merzlota system. The modeling involved 3D reconstructions of ice sheets and major relevant processes in time, with variable interval of time slices up to $1 \mathrm{ka}$ for the last deglaciation. The determination of zones of fast-flowing ice streams and stagnation included detailed bedrock grid analysis and special filtering with joint analyses of special grids of geological and tectonic content, including average relative erosion resistance. Erosion velocities were estimated in changing conditions, like possible distribution of interglacial sediments with a very low resistance, permafrost, etc. The modeling simulated landscape development to compare with the observed pattern. Extensive data were used to characterize the subsurface geology.

\section{Discussion and conclusions}

The first-order pre-glacial landscape elements were among the major factors that could partly control ice basal velocities in favorable circumstances. In time, many relevant basins were in various degree modified by glacial and periglacial erosion and sedimentation. Dominantly they represent structural-denudational forms, when their location was predefined by tectonic structures of different kind, like old grabens or structural basins, sutures, dense fault zones, etc.

Selective erosion processes created cuesta-like topography at the monoclines, which framed parts of the Baltic and Canadian shields, with usual combination of a gentle backslope on one side, and a steeper front slope on the other. Such combination shaped several belts in common agreement with margins of Pleistocene ice sheets, so we call them "marginal" lowlands. They control numerous huge bedrock (and surficial) landforms, occupied by large lakes as well. The lowermost extensive back slope of this tilted "staircase" is usually comprised of the exhumed planated crystalline basement, but with sedimentary sequence of the front slope. More intensively eroded fragments along the Canadian shield's margin are exhibited by the southern part of Great Bear Lake (65.4 N, 120 W), Lac La Martre (63.4 N, $118 \mathrm{~W}$ ), the North Arm of Great Slave Lake (62.2 N, 115 W), Lake Winnipeg (53 N, 98 W). Direct equivalents along the margin of the Baltic shield are 
Western and Northern parts of the Baltic Proper with the Gulf of Finland (59.6 N, 24 E), or Onega Bay (64.4 $\mathrm{N}, 36.7 \mathrm{E})$ and Gorlo Strait (66.3 N, 40.8 E) of the White Sea. Lake pro-glacial episodes in the history of both inland seas are well known.

The cuesta-like "staircase" landscape in the sedimentary domains controlled, for example, Winnipegosis (52 N, $100 \mathrm{~W}$ ), Manitoba (50.5 N, 98.3 W), Michigan (44 N, 87 W), Guron (44.6 N, 82.5 W) and Erie (47.6 N, $87 \mathrm{~W}$ ) lakes in North America. In Northern Europe the mentioned Lake Beloye and Lake Lacha (61.31 N, 38.75 E) have comparable position. Both basins were located at the footslope in the same more friable horizon of the Upper Carboniferous strata, with intensive karstification and the beginning of presence of gypsum (more common in younger Lower Permian strata), which was subjected to dissolution. Both basins were also shaped in the axial parts of ice-streams, but with convergence in the case of the Lake Beloye. The frontslope in the Permian rocks was intensively eroded in the case of the Lake Lacha, with the excavation of elongated lowland occupied by the Lake Vozhe (60.58 N, 39.08 E) further south. However the frontslope served as a barrier southeast of the Lake Beloye, generating ice rotational movement and detached bedrock masses of a hill-hole variant. Key features of aquifers and ground-water systems of this area could be of additional importance.

However the most profound deeper basins were shaped around the lowermost marginal lowland, but in transverse radial ice-stream zones, when they followed different specific tectonic basins, commonly as old as Mesoproterozoic. Two major subtypes can be distinguished:

1. Elongated troughs with glacial overdeepenings caused by erosion of friable non - or weeklymetamorphosed sediments of the tectonic basin, but with possible continuation of the erosional landform in other sedimentary formations in agreement with dominate ice motion (e.g. Arms of the Great Bear Lake (66 N, 120 W), Lake Superior (47.6 N, 87 W), Kandalaksha-Dvina Bays (65.7 N, 36.9 E) of the White Sea). The giant glacial cirques like the North Lake Ladoga (Severoladozsky $(61.2 \mathrm{~N}, 31 \mathrm{E})$ ) or the Landsort deep (58.57 N, 18.54 E) with the deepest point of the Baltic Sea could be excavated in specific conditions. Without the distinct deep tectonic basin the overdeepened part could be displaced to the cross-point with the marginal lowland, as in the Great Slave Lake at $\sim 61.7 \mathrm{~N}, 114 \mathrm{~W}$;

2 . Troughs with moderate peripheral deepening of the tectonic basins with positive (inversed) bedrock landscape. In this case the old tectonic basins were comprised by resistant rocks (e.g. quartzite) and thus the radial lowlands were displaced to the unconformity or more erodible unit along the margin (Lake Athabasca (59.2 N, 109 W), Lake Onega (61.5 N, 35.4 E)).

The combination of marginal and radial lowlands is usual in glaciated areas, but different geological and tectonic settings, and geological history influenced the pattern of glacial erosion. In few cases the sediment compaction in tectonic basins could be mentioned as important additional factor, like in the case of the Lake Taimyr (74.5 N, 101.6 E), where the compaction of thick pile of the Upper Cretaceous sediments in the tectonic basin controlled the younger sedimentation and further erosion during the shaping of marginal lowland.

\section{Acknowledgements}

The research was performed at a base of RFBR project 19-05-00768, RSF project 17-77-20041, and scientific theme in the Institute of Limnology, RAS (registration number 01201363380).

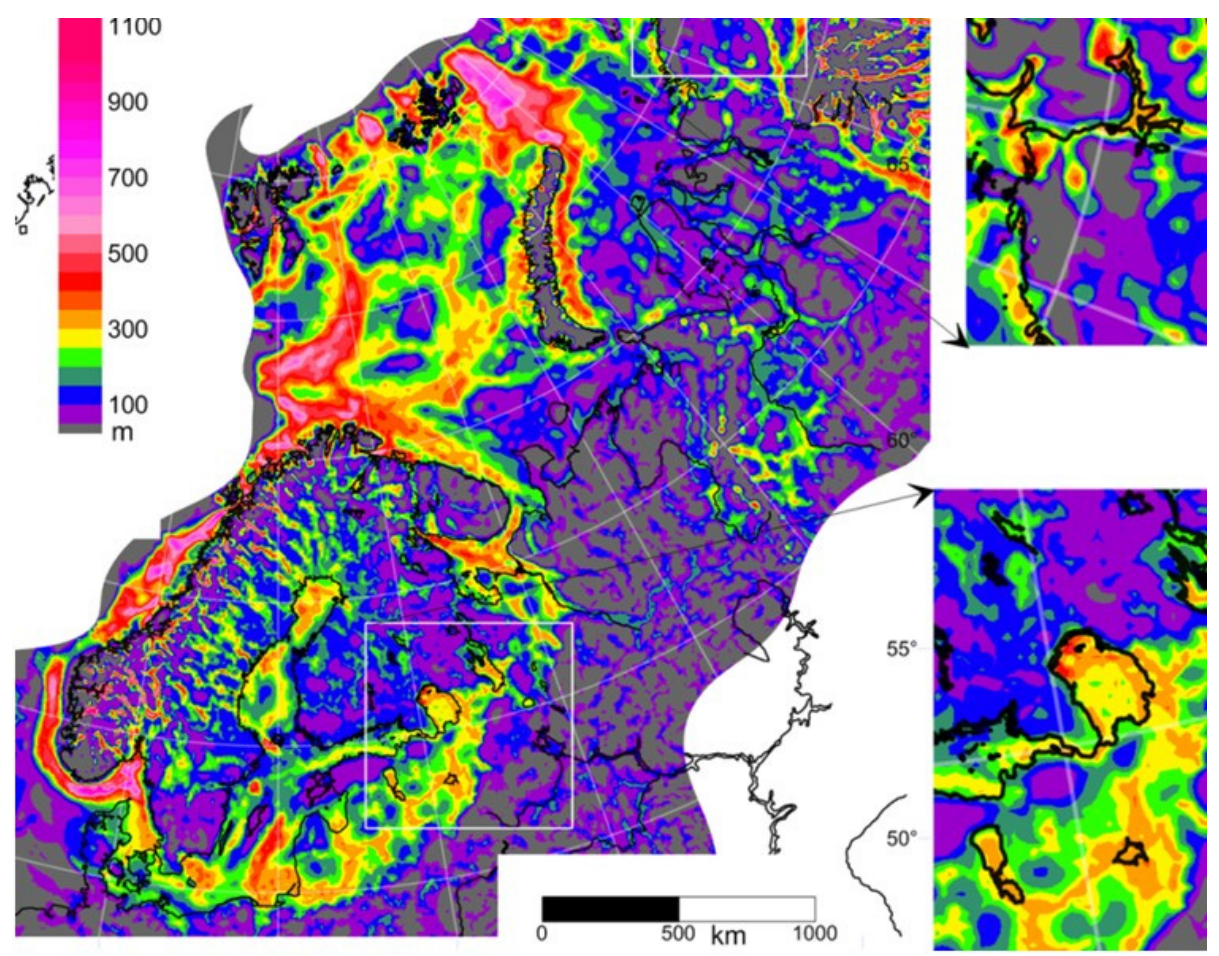

Fig.1. Generalized Quaternary erosion (bedrock lowering) with inset maps for the large lakes region (below) and the Lake Taimyr area 